\title{
Comparison of High School Student's Learning Outcomes Using Cooperative Learning Model Between Think Pair Share (TPS) and Teams Games Tournament (TGT) Types on Reaction Equation
}

\author{
*Nurlia L. Radjabani, Ratman \& Purnama Ningsih \\ Pendidikan Kimia/FKIP - Universitas Tadulako, Palu - Indonesia 94119 \\ Received 8 December 2020, Revised 12 January 2021, Accepted 8 February 2021 \\ doi: 10.22487/j24775185.2021.v10.i1.pp20-25
}

\begin{abstract}
This study aimed to describe the difference between students' learning outcomes from the class using the cooperative learning model of think pair share (TPS) type and teams games tournament (TGT) type on the topic of reaction equation in class $X$ at MAN 2 Model Palu. This study was a pre-experiment with the static group pretest-postest design. This study was conducted in two groups i.e., class XA as experiment group $1(n=24)$ and Class XB as experiment group $2(n=23)$. Data of students' learning outcomes were analyzed using $t$-test twoparty statistical analysis with the prerequisite of normality and homogeneity tests of the data from the given posttest. The analysis results obtained the average score of experimental class 1 (IX) was 68.25, while the average score of the control class $(2 X)$ was 63.15 . The hypothesis test results obtained $t_{\text {count }}=2.47$ and $t_{\text {table }}=2.02$ with significance level $=0.05$ and degrees of freedom 45 , then $H_{0}$ was rejected, and $H_{a}$ was accepted. Based on these results, it can be concluded that students' learning outcomes from the class using the cooperative learning model of think pair share (TPS) type is different from the class using cooperative learning model of teams games tournament (TGT) type on the topic of reaction equation in the Class X at MAN 2 Model Palu. Students' learning outcomes in experimental class 1 were higher than in experimental class 2.
\end{abstract}

Keywords: Cooperative learning, think pair share (TPS), teams games tournament (TGT), learning outcomes, reaction equation

\section{Introduction}

Education has a very strategic role in improving the quality of human resources and efforts to realize the ideals of the Indonesian nation in recognizing the general welfare and educating the life of the country. The government formulates in the Law of the Republic of Indonesia No. 20 of 2003 Article 1 of the National Education System, which explains that "Education is a conscious and planned effort to realize the learning process and learning process so that learners actively develop their potential to have religious-spiritual power, selfcontrol, personality, intelligence, noble character, as well as the necessary skills of themselves, the people of the nation and state" (Astika \& Nyoman, 2011).

Success in the teaching and learning process is inseparable from teacher readiness and student readiness. Students are required to have an interest and motivation for the subject matter, as well as a teacher is required to master the material to be taught and be able to choose the right teaching method to create good educational interactions, theoretically and empirically. One of the factors that cause students less interest and difficulty in learning chemistry is the use of monotonous and inappropriate teaching strategies and methods. Moreover, chemistry lessons are loaded with complex concepts, chemical formulas, and chemical calculations (Muharram \& Jusniar, 2012).

Chemistry subjects are subjects that require a broad understanding of concepts in understanding each material because it relates to something abstract, ranging from simple concepts to complex concepts. So it is necessary to understand the correct concept in studying chemistry subjects (Sinaga, 2010). The use of student-centered learning patterns is certainly expected to realize conducive conditions that encourage students to be motivated to actively conduct learning activities. The reality in the field shows that the achievement of an efficient teaching and learning process, not only with teacher-centered methods of one-way communication but also with multi-way learning methods or student-centered learning. If this does not synergize, it will affect the quality of education to be low. The curriculum 2013 is a studentcentered learning process activity that requires the use of approaches, strategy, methods, and techniques of learning in accordance with the

*Correspondence:

Nurlia L. Radjabani

e-mail: nurliaradjabani@gmail.com

(c) 2021 the Author(s) retain the copyright of this article. This article is published under the terms of the Creative Commons Attribution License 4.0, which permits unrestricted non-commercial use, distribution, and reproduction in any medium, provided the original work is properly cited. 
approach to involve active student participation in the learning process (Durukun, 2011).

One of the schools that implemented the 2013 curriculum in Kota Palu is MAN 2 Model Palu. Based on observations at MAN 2 Model Palu school, researchers found that most students are less active in studying chemical material that is not applied in experiments or varied learning media. This can be due to monotonous learning methods.

Achievement as a result of learning can be influenced by various factors. Factors that can influence the learning process and outcomes in students include internal and external factors. Internal factors are factors contained in the student, namely the level of student intelligence, ability, attitude, talent, interest, and motivation of the student. In comparison, external factors such as learning methods and media are chosen by teachers (Putri et al., 2013).

According to Suryani (2013), the quality of learning needs to be improved to improve the quality of education so that a lot of special attention is directed to the development and progress of education in order to improve the quality and quality of education, especially in chemical learning. One of them is by implementing a strategy or effective learning methods in the classroom and more empowering the potential of students.

Based on these problems, there needs to improve in the learning system. Fun learning and easy material delivery for students to understand are essential to increase students' learning interest. Cooperative learning models maximize learning activities by grouping students in small groups and together. Students not only listen but participate in all learning processes so that the information and knowledge can not be quickly forgotten (Nazamin, 2013).

Various learning models that are oriented towards student activities today have been widely expressed (Kusuma \& Aisyah, 2012). Many learning models are offered, which can be applied to improve student learning outcomes including, think-pair-share (TPS) and teams gamestournament (TGT) cooperative learning models.

Cooperative learning type think-pair-share is a cooperative learning model that students in pairs to complete academic tasks through three stages, namely think, pair and share. One of the priorities of the cooperative learning model tps type is to foster student involvement and participation by providing open opportunities for students to speak and express their own ideas and motivate students to engage in conversation in the classroom. The use of TPS-type cooperative learning models can help students communicate chemistry to convey information, such as expressing ideas, asking questions, and responding to other student's questions (Marlina \& Ikhsan, 2014).

Team games-tournament type cooperative learning model is learning that is accompanied by games. In this model, students play games with other team members to earn extra points for their team scores (Trianto, 2010). TGT cooperative learning model will cause a sense of excitement because games and tournaments are fun, so that sometimes learners feel indirect, not doing the learning. In this way, students will feel a more pleasant atmosphere, interest, and motivation to learn is also increased so that learning outcomes can be maximized (Pawestri, 2009).

The application of the cooperative learning model is not a new thing to do in MAN 2 Palu Model. Teachers at MAN 2 Palu Model have also implemented several cooperative learning models such as jigsaw and STAD. However, these cooperative models are still combined with conventional methods, usually also used in the form of animation media for certain materials, but not yet effective and managed adequately. Therefore, researchers are interested in applying cooperative learning models of TPS and TGT types that are expected to be used as an alternative in solving problems that arise during the learning process and efforts to improve student learning outcomes in reaction equation materials.

This paper is intended to describe the results of chemistry learning between classes that use tps type cooperative learning model with classes that use TGT type cooperative learning model on reaction equation materials in class X MAN 2 Palu Model.

\section{Method}

This research was conducted in MAN 2 Palu Model. This type of research is weak experimentation with the design of the statistic group pretest-postttest design. The population of this research is all $\mathrm{X}$ grade students with sampling techniques that is purposive sampling method. The sample used was XA class students as experiment class $1(n=24)$ with the number of female students as many as 14 students while the number of male students as many as ten students and students of class $\mathrm{XB}$ as experimental class $2(\mathrm{n}=23)$ with the number of female students as many as 12 students while the number of male students as many as 11 students.

\section{Research Instruments}

The test instrument used in this study is in the form of multiple-choice questions totaling 40 questions with each answer option. There are 5 alternative options provided (A, B, C, D, E). Assessment of this test instrument through two stages, namely pretesting to find out the students' initial ability before treatment and postest given after treatment on the research sample to find out the mastery and learning outcomes of students to the material given. Before this test is used to retrieve data, the problem item analysis is first done to determine the validity, reliability, difficulty level, and differentiating power. 


\section{Data Analysis Techniques}

Data analysis in this study consists of prerequisite tests (normality tests and homogeneity tests) and hypothesis tests. The hypothesis test uses inferential statistical analysis, which is often referred to as inductive statistics that is the statistical phase related to the conditions in which such conclusions are drawn (Sudjana, 2010).

\section{Results and Discussion}

Based on the data of the research results, data obtained about the learning outcomes of students in experiment class 1 and the learning results of students of experiment class 2 were obtained from the posttest score (final test) on the reaction equation material. Data on posttest results on reaction security material can be seen in Table 1 .

Table 1. Comparison of learning outcomes of students in experiment class 1 and 2

\begin{tabular}{ccc}
\hline \multirow{2}{*}{ Description } & \multicolumn{2}{c}{ Post-test } \\
& Experiment Class 1 & Experiment Class 2 \\
\hline Sampel & 24 & 23 \\
Lowest Score & 50 & 45 \\
Highest Score & 85 & 80 \\
Average & 68.25 & 63.15 \\
Standard Deviation & 10.44 & 9.86 \\
\hline
\end{tabular}

Based on Table 1, it can be seen that the average score in experiment class 1 is higher than in experiment class 2 . This shows that the learning outcomes obtained in experimental class 1 are better than in experiment class 2 , so that it proves that there are differences in student learning outcomes between classes that use TPS-type cooperative learning models and classes that use TGT-type cooperative learning models in reaction equation materials in class X MAN 2 Palu Model.

Based on the analysis results in Table 2, it can be seen that the data was normal and homogeneous since both data groups showed the value of $\leq 1000$ and $\mathrm{F}_{\text {count }}<\mathrm{F}_{\text {table, }}$ which means that meets the requirements to conduct hypothesis testing, then the hypothesis test is carried out using a two-party t-test. This hypothesis test was conducted to find out if there are differences in student learning outcomes between classes that use TPS-type cooperative learning models and classes that use TGT learning models in reaction equation materials in class X MAN 2 Palu Model. The results of the analysis with a two-party $\mathrm{t}$-test obtained $\mathrm{t}_{\text {count }}$

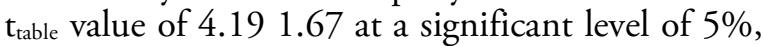
then the $\mathrm{H}_{0}$ hypothesis was rejected, and the $\mathrm{H}_{1}$ hypothesis was accepted. This means that students who use the tps type cooperative learning model are higher than the learning outcomes of students who use TGT learning model in Reaction Equation material in class X MAN 2 Palu Model. Rejection of the $\mathrm{H}_{0}$ hypothesis was also supported by the average value obtained in both classes, and it can be concluded that there is a difference in student learning outcomes between experimental 1 and experimental 2, namely the learning outcomes of students who use the TPS type cooperative learning model is higher than the learning outcomes of students who use the TGT learning model in the Reaction Equation material in grade X MAN 2 Palu Model.

The price of $\mathrm{t}(0.95)$ with $\mathrm{dk}=45$ of the student distribution list is 2.00 . The test criteria is if $-\mathrm{t}_{\text {table }} \leq \mathrm{t}_{\text {count }} \leq+\mathrm{t}_{\text {table }}(1-\alpha),(\mathrm{n} 1+\mathrm{n} 2-2)$ receive $\mathrm{H}_{0}$ and $\mathrm{H}_{\mathrm{a}}$ is rejected (Riduwan, 2010). Based on the results obtained, $-2.02<2.47>+2.02$ is clearly in the rejection area $\mathrm{H}_{0}$, so $\mathrm{H}_{0}$ is rejected, and $\mathrm{H}_{a}$ is accepted. Thus, it can be concluded that there are differences in student chemistry learning outcomes between classes that use TPS-type cooperative learning models and classes that use TGT-type cooperative learning model learning in reaction equation materials in class X MAN 2 Palu Model.

Table 2. Normality test results, homogeneity test, and statistical test on student learning outcomes in reaction equation material

\begin{tabular}{ccccccccc}
\hline \multirow{2}{*}{ Class } & \multirow{2}{*}{$\mathrm{N}$} & \multicolumn{5}{c}{ Test Normality } & \multicolumn{3}{c}{ Homogeneity Test } & $\mathrm{t}$-test \\
\cline { 2 - 8 } & & $\mathrm{X}_{\text {hit }}^{2}$ & $\mathrm{X}_{\text {tab }}^{2}$ & Conclusion & $\mathrm{F}_{\text {count }}^{2}$ & $\mathrm{~F}_{\text {tab }}^{2}$ & Conclusion & \\
\hline Experiment 1 & 24 & 6.14 & 7.81 & & & & $\mathrm{~T}_{\text {count }}=2.47$ \\
\hline & & & $\begin{array}{l}\text { Distributed } \\
\text { normally }\end{array}$ & 1.12 & 2.04 & Homogeneous & \\
\hline Experiment 2 & 23 & 4.72 & 7.81 & & & & $\mathrm{t}_{\text {tab }}=2.02$ \\
\hline
\end{tabular}

Based on research conducted in experiment class 1 and experiment class 2, both classes have almost the same ability; this can be seen from the average score that has been obtained from both classes. But each student from each class has different abilities. The students' ability is students who have good ability and diligently obtain better learning outcomes, students who have the good ability but are less diligent do not show satisfactory results, students who have the low ability but diligently obtain learning results that are still lacking, and there are also students who have the low ability and do not diligently obtain very low learning results. So that during the learning process, 
there are students who can not keep up with other students and result in students who miss out on learning. Students who had missed out on the learning process eventually became lazy to adjust to other friends because not understanding the material taught again caused this student to become passive during the learning, which resulted in unsatisfactory learning outcomes. So that the application of TPS-type cooperative learning model in experiment class 1 , researchers considered the condition of the student before determining his partner, in this case, the researcher determined the pair of students, where the student who obtained the score was very high paired with students who had low scores. While the application of TGT-type cooperative learning models in the class of experiment 2, consisting of 4-5 students, researchers grouped moderate and low-skilled students into 1 group, so that in both classes, namely experiment class 1 and experiment class 2, the ability of each group was balanced. One of the factors that cause low student learning achievement is the learning model used by teachers (Andriani et al., 2013).

The difference in student learning outcomes between experiment class 1 and 2, namely the student's learning outcomes in experiment 1 is higher than the student's learning outcomes in 2 shows that tps-type cooperative learning models have an influence on student learning outcomes. The results of this study were also supported by differences in variance values obtained from the two classes, namely the largest variant of 108.98 while the smallest variance is 97.33 , so it can be concluded that chemistry learning with tps type cooperative learning model has a positive influence on student learning outcomes. TPS cooperative learning model is able to involve active students so that learning becomes meaningful (Alpusari \& Putra, 2015).

The level of effectiveness of learning is not only seen from the students' learning outcomes, but the effectiveness of learning is also emphasized on the level of teacher's ability to manage learning and the level of teacher mastery of learning strategies, and the level of appropriateness of time used during the process (Mustapa, 2009).

Based on the results of the analysis obtained above, shows that the TPS type cooperative learning model in reaction equation material provides better learning outcomes compared to TGT learning models. This is in accordance with the research results of Nugraha et al. (2013), which showed that tps-type cooperative learning models effectively improve student learning achievement at SMA Negeri 2 Karanganyar. Tps type cooperative learning model can improve student learning activities and achievements, namely in affective and cognitive aspects (Jannah et al., 2013). Think pair share learning models are cooperative learning strategies where students think about their responses to solve problems provided by instructors and then discuss their individual solutions in pairs and share solutions with other partners (Dol, 2014).
According to Efendi (2013), TPS-type cooperative learning models syntax can increase students' awareness to motivate themselves to understand the knowledge to be achieved. According to Zuhara \& Azizah (2014), at the think and pair stage, honest character and responsibility can be raised through the honesty of students in working on the questions given at each stage and responsibility in solving all the problems given. In pairs, students have the opportunity to think hard with other students about their responses before being asked to share their ideas. This strategy provides an opportunity for all students to share their thoughts with at least one other student. This increases the sense of student involvement in the study (Sugiarto \& Sumarsono, 2014).

This is in line with Siburian (2013) that students' achievements increase when they are taught with TPS-type cooperative learning models. The implementation of tps type cooperative learning model is an activity to ask students to reflect on the problem and then share their thoughts with others. Students get the urge to justify their attitudes by using clear examples and clarity of thought and expression. Students gain a conceptual understanding of the material and gain practice in using other student's opinions to build their own ideas and are trained to learn collaboratively (Tint \& Nyunt, 2015).

The results of this study provide the same results as the research conducted by Nasution \& Surya (2017), which states that learning using TPS cooperative learning can be used as an alternative in improving student learning outcomes. cooperative learning think pair share is stated as an effective teaching focus on students to do their skills in togetherness in all classroom activities to improve their competence in language skills (Usman, 2015).

Nevertheless, the study was found some obstacles. The implementation of this TGT learning model is required for teachers to be able to master the classroom and be able to control students' skills during games, especially in supervising each group work so that there is no cheating in the game and in controlling the time needed to solve the given problem. While in the application of tps learning model that is many groups who report being guided, the number of couples formed quite a lot so that it takes more time as well, and this method is difficult to apply to classes with an odd number of students, so from the observations made researchers chose classes with even numbers to overcome these obstacles. Other obstacles researchers can overcome by providing early understanding to students as well as strict controls in the application of learning methods. One of the priorities of TPS-type cooperative learning model is that it can foster student engagement and participation by providing open opportunities for students to speak and express their ideas and motivate students to engage in classroom conversations (Irawati et al., 2015). Think-pairshare techniques also improve the study of oral 
communication and skills because they have enough time to discuss them, ideas with each other so that the responses received are often more intellectually concise because students have the opportunity to reflect on their ideas (Azlina, 2010). Thus, the tps type cooperative learning model provides opportunities for students to play an active role in hypothesizing, discussing with their spouses, sharing with other partners, maximizing students' knowledge through teacher guidance, and encouraging students to find their knowledge through learning together.

\section{Conclusions}

There are differences in student learning outcomes between the experimental class 1 and the experiment class 2 , namely the learning outcomes of students who use the TPS type cooperative learning model is higher than the learning outcomes of students who use the TGT type cooperative learning model in the Reaction Equation material in class X MAN 2 Palu Model. This can be seen from the average posttest score of each class, i.e. in the experiment class $1=68.25$ and the experiment class $2=63.15$. This is reinforced by statistical analysis where $\mathrm{t}$-test analysis is obtained $-<\mathrm{t}_{\text {count }}>+\mathrm{t}_{\text {table }}$, ( $2,021<2,475>+2,021)$ with a significant level of 0.05 .

\section{Acknowledgments}

The authors would like to express their deep gratitude to the principal, chemistry teacher, and grade X MAN 2 student Model Palu as well as all those who have helped the author in completing this research.

\section{References}

Alpusari, M., \& Putra, R. A. (2015). The application of cooperative learning think pair share (TPS) model to increase the process science skills in class iv elementry school number 81 Pekanbaru city. International Journal of Science and Research (IJSR), 4(4), 2805-2808.

Andriani, D. G., Atmojo, K. T., \& Mardiyana. (2013). Eksperimentasi model pembelajaran kooperatif tipe jigsaw II dan think pair share ditinjau dari kecerdasan emosional siswa smp se-kota kediri tahun pelajaran 2012/2013. Jurnal Elektronik Pembelajaran Matematika, 1(7), 651-660.

Astika, N., \& Nyoman, N. A. (2011). Efektivitas model pembelajaran kooperatif tipe make a match terhadap hasil belajar. Jurnal Penelitian Pembelajaran Fisika, 3(2), 110-117.

Azlina, N. A. N. (2010). CETLs: Supporting collaborative activities among students and teachers through the use of think-pair-share techniques. IJCSI International Journal of Computer Science Issues, 7(5), 18-29.

Dol, S. M. (2014). TPS (think-pair-share): An active learning strategy to teach theory of computation course. International Journal of Educational Research and Technology, 5(4), 6267.

Durukun, E. (2011). Effects of cooperative integrated reading and composition (CIRC) technique on reading-writing skills. Educational Research and Reviews, 6(1), 102-109.

Efendi, N. (2013). Pengaruh pembelajaran reciprocal teaching dipadukan think pair share terhadap peningkatan kemampuan metakognitif belajar biologi siswa SMA berkemampuan akademik berbeda di Kabupaten Sidoarjo. Jurnal Santiaji Pendidikan, 3(2), 85-109.

Irawati, S., Budiyono., \& Slamet, I. (2015). Eksperimentasi model pembelajaran kooperatif tipe pairs check (PC), think pair share (TPS), dan problem based learning (PBL) pada materi kubus dan balok ditinjau dari gaya belajar siswa kelas viii SMP negeri se-kota surakarta. Jurnal Elektronik Pembelajaran Matematika, 3(2), 754-765.

Jannah, R., Saputro, C. N. A., \& Yamtinah, S. (2013). Penerapan model pembelajaran thinkpair share (TPS) disertai buku saku untuk meningkatkan aktivitas dan prestasi belajar kimia pada materi minyak bumi kelas X SMA Negeri Gondangrejo tahun pelajaran 2012/2013. Jurnal Pendidikan Kimia (JPK), 2(4), 19-23.

Kusuma, F. W., \& Aisyah, M. N. (2012). Implementasi model pembelajaran kooperatif tipe think pair share untuk meningkatkan aktivitas belajar akuntansi siswa kelas XI IPS 1 SMA Negeri 2 Wonosari tahun ajaran 2011/2012. Jurnal Pendidikan Kimia (JPK), 2(3), 19-23.

Marlina, H., \& Ikhsan, M. (2014). Penggunaan model pembelajaran kooperatif tipe think pair share (TPS) untuk meningkatkan kemampuan komunikasi dan disposisi matematis siswa di SMA Negeri 1 Bireuen. Jurnal Didaktik Matematika, 1(1), 83-95.

Muharram., \& Jusniar. (2012). Meningkatkan partisipasi siswa kelas XI SMAN 3 Sungguminasa melalui pembelajaran penemuan terbimbing pada materi pokok senyawa hidrokarbon. Chemica: Jurnal Ilmiah Kimia dan Pendidikan Kimia, 13(1), 68-76.

Mustapa, K. (2009). Efektivitas pembelajaran problem posing dalam meningkatkan hasil belajar dan motivasi mahasiswa kimia Universitas Tadulako. Disertasi Tidak Diterbitkan. Malang: Universitas Negeri Malang.

Nasution, Y. S., \& Surya, E. (2017). Application of tps type cooperative learning in improving students' mathematics learning outcomes. International Journal of Sciences: Basic and Applied Research (IJSBAR), 34(1), 116-125.

Nazamin. (2013). Penerapan model pemebelajaran kooperatif tipe teams-games-tournament (TGT) 
untuk meningkatkan prestasi beajar matematika siswa kelas VMI Ma'rifKediwung Dlingo Bantul tahun pelajaran 2012/2013. Skripsi Tidak Diterbitkan. Yogyakarta: Universitas Islam Negeri Sunan Kalijaga.

Nugraha, D., Susanti, E., \& Masykuri, M. (2013). Efektivitas metode pembelajaran kooperatif think pair share (TPS) yang dilengkapi media kartu berpasangan (Index Card Match) terhadap prestasi belajar siswa pada materi ikatan kimia kelas X semester gasal SMAN 2 Karanganyar tahun pelajar 2012/2013. Jurnal Pendidikan Kimia (JPK), 2(4), 174-181.

Pawestri, D. C. (2009). Penerapan model pembelajaran kooperatif teams games tournament (TGT) pada mata pembelajaran ekonomi sebagai upaya meningkatkan hasil belajar siswa kelas $X$ SMA Muhammadiyah 3 Surakarta tahu pelajaran 2008/2009. Skripsi Tidak Diterbitkan. Surakarta: Universitas Sebelas Maret.

Putri, P. I., Martini, S. K., \& Nurhayati, D. N. (2013). Penerapan metode pembelajaran teams games tournament (TGT) dilengkapi kartu destinasi untuk meningkatkan minat dan prestasi belajar pada materi minyak bumi kelas X 5 SMA Negeri Gondangrejo tahun pelajaran 2012/2013. Jurnal Pendidikan Kimia (JPK). 2(4), 90-95.

Riduwan. (2010). Pengantar statistik untuk penelitian pendidikan, sosial, ekonomi, komunikasi dan bisnis. Bandung: Alfabeta.

Siburian, T. A. (2013). Improving students' achievement on writing descriptive text through think pair share. International Journal of
Language Learning and Applied Linguistics World (IJLLALW), 3(3), 30-43.

Sinaga, S. (2010). Konsep dan makna pembelajaran. Bandung: Alfabeta.

Sudjana. (2010). Metode statistik. Bandung: PT. Tarsito.

Sugiarto, D., \& Sumarsono, P. (2014). The implementation of think-pair-share model to improve students' ability in reading narrative texts. International Journal of English and Education, 3(3), 206-215.

Suryani. (2013). Efektivitas pembelajaran kooperatif tipe teams games tournmant (TGT) dan numbered heads together (NHT) terhadap keaktifan dan hasil belajar matematika siswa kelas VII SMP Muhammadiyah 8 Yogyakarta. Skripsi Tidak Diterbitkan. Yogyakarta: UIN Sunan Kalijaga.

Tint, S. S., \& Nyunt, E. E. (2015). Collaborative learning with think pair share technique. Computer Applications: An International Journal (CAIJ), 2(1), 1-11.

Trianto. (2010). Mendesain model pembelajaran inovatif-progresif. Jakarta: Kencana.

Usman, A. H. (2015). Using the think-pair-share strategy to improve students' speaking ability at stain ternate. Journal of Education and Practice, 6(10), 37-45.

Zuhara, M. \& Azizah, U. (2014). Penerapan model pembelajaran kooperatif tipe think-pair-share (TPS) untuk mengembangkan karakter siswa pada materi larutan elektrolit dan nonelektrolit di SMA 17 agustus 1945. UNESA Journal of Chemical Education, 3(2), 61-66. 